\title{
Залежність виникнення післяопераційної когнітивної дисфункціі від глибини анестезіі у хворих після коронарного шунтування
}

\author{
С. М. Судакевич ${ }^{1,2}$, О. А. Лоскутов ${ }^{1,2}$, І. П. Шлапак ${ }^{2}$, О. К. Носовець ${ }^{3}$, Б. М. Тодуров ${ }^{1,2}$ \\ ${ }^{1}$ Інститут серця МОЗ України, м. Київ, \\ ${ }^{2}$ Національна медична академія післядипломної освіти імені П. Л. Шупика, м. Київ, \\ ${ }^{3}$ Національний технічний університет України «Київський політехнічний інститут імені Ігоря Сікорського», м. Київ
}

\section{Dependence of the postoperative cognitive dysfunction occurrence on the anesthesia depth in patients after coronary shunting}

\author{
S. M. Sudakevych ${ }^{1,2}$, O. A. Loskutov ${ }^{1,2}$, I. P. Shlapak $^{2}$, O. K. Nosovets ${ }^{3}$, B. M. Todurov ${ }^{1,2}$ \\ ${ }^{1}$ Institute of the Heart, Kyiv, \\ ${ }^{2}$ Shupyk National Medical Academy of Postgraduate Education, Kyiv, \\ ${ }^{3}$ National Technical University of Ukraine «Igor Sikorskyi Kyiv Polytechnic Institute», Kyiv
}

\section{Peфepar}

Мета. Проаналізувати залежність виникнення післяопераційної когнітивної дисфункції (ПОКд) від глибини анестезії у хворих після оперативного втручання з приводу ішемічної хвороби серця (IXC) - коронарного шунтування в умовах штучного кровообігу. Матеріали і методи. Шунтування коронарних судин виконано 79 пацієнтам з IXC, яких розподілили на дві групи за єдиним критерієм - в залежності від глибини анестезії під час перфузії. До 1-ї групи увійшли пацієнти, у яких під час анестезії показник біспектрального аналізу (BIS) утримувався на рівні менше 40, до 2-ї - на рівні від 40 до 55. До оперативного втручання, на 7-й день та через 3 міс після нього в обох групах застосовували нейрокогнітивні тести: шкалу оцінки психічного статусу (Мin Mental state examination - MMSE), а також тести за методикою Grooved pegboard і за методикою Trial Making Test Part A. Результати. Застосування тесту MMSE продемонструвало, що пацієнти 1-ї групи на 7-й день після операції набирали на 7,8\% $(14,2 ; 5,6)$, а через 3 міс - на 3,8\% $(7,3 ; 3,4)$ менше балів у порівнянні 3 кількістю балів, яку вони набирали до операції. Пацієнти 2 -ї групи на 7 -й день після операції набирали на 4,3\% $(-8,3 ; 4,3)$ менше балів, а загальна кількість балів, яку вони набирали через 3 міс, не відрізнялася від загальної кількості балів, набраної ними до операції $(-5,3 ; 0)$. Застосування тесту візуальної уваги (Trial making test Part A) показало, що паціенти 1-ї групи на 7-й день після операції витрачали на виконання тестового завдання на $13,8 \%(11 ; 16,5)$, а через 3 міс - на $3,3 \%(0 ; 5,7)$ більше часу у порівнянні з доопераційними показниками. У 2 -й групі на 7 -й день після операції паціенти витрачали на виконання тесту на $3 \%(-2,4 ; 5,7)$ більше часу, а через 3 міс - на $2,6 \%(3,7 ; 2,9)$ менше часу, ніж до операції. Результати тестування за методикою Grooved pageboard були такими. Пацієнти 1-ї групи на 7-й день після операції витрачали на виконання тесту на 8\% $(5,5 ; 10,9)$, а через 3 міс - на 4,8\% $(2,5 ; 9,4)$ більше часу, ніж до оперативного втручання, пацієнти 2-ї групи - відповідно 7,1 (5,2; 12,3) та 3,6\% (2,4; 9,8).

Висновки. Результати клінічних досліджень у хворих після виконання коронарного шунтування показали, що під час штучного кровообігу показники BIS на рівні 40 - 55 відповідають оптимальній глибині анестезії, що є запорукою зменшення частоти виникнення ПОКД у ранньому періоді та через 3 міс після оперативного втручання. Фактором ризику виникнення ПОКД під час шунтування коронарних артерій в умовах штучного кровообігу є показники BIS менші 40.

ключові слова: глибина анестезії; штучний кровообіг; когнітивна дисфункція; аортокоронарне шунтування.

\section{Abstract}

Objective. To analyze the dependence of the postoperative cognitive dysfunction (POCD) occurrence on the anesthesia depth in patients after coronary shunting, performed for ischemic heart disease (IHD) in conditions of the artificial blood circulation application. Materials and methods. The coronary vessels shunting was performed in 79 patients, suffering the IHD, who were divided into two Groups, depending on one criterion - the anesthesia depth during perfusion. Into Group I the patients were included, in whom during anesthesia a bispectral analysis index (BIS) have had persisted on the level lower than 40, while into Group II - on the level from 40 to 55. Preoperatively, on the $7^{\text {th }}$ day and in 3 mo in both Groups the neurocognitive tests were applied: a scale of psychological state estimation (Mini Mental state examination - MMSE), as well as the tests in accordance to Grooved pegboard procedure and in accordance to the Trial Making Test Part A procedure.

Results. Application of the MMSE test have demonstrated, that the Group I patients on the $7^{\text {th }}$ postoperative day have gained by $7.8 \%$ $(14.2 ; 5.6)$, and in $3 \mathrm{mo}$ - by $3.8 \%$ (7.3; 3.4) lesser points, comparing with the points they gained preoperatively. The Group II patients on the $7^{\text {th }}$ postoperative day have gained by $4.3 \%(-8.3 ; 4.3)$ lesser points, while a total quantity of points they gained in 3 mo did not differ from the sum of points they gained preoperatively $(-5.3 ; 0)$. The visual attention testing (Trial making test Part A) application have shown, that the Group I patients on the $7^{\text {th }}$ postoperative day have wasted by $13.8 \%(11 ; 16.5)$, and in 3 mo - by $3.3 \%(0 ; 5.7)$ more time for the testing task performance, comparing with preoperative values. In the Group II on the $7^{\text {th }}$ postoperative day the patients have wasted by $3 \%(-2.4 ; 5.7)$ more time, and in $3 \mathrm{mo}-$ by $2.6 \%(3.7 ; 2.9)$ lesser time for the test performance, than preoperatively. The testing results in accordance to the Grooved pageboard procedure were following. The Group I patients on the $7^{\text {th }}$ postoperative day have wasted by $8 \%(5.5 ; 10.9)$, and in $3 \mathrm{mo}$ - by $4.8 \%(2.5 ; 9.4)$ more time for the testing performance, than preoperatively, while the Group II patients - 7. $(5.2 ; 12.3)$ and $3.6 \%(2.4 ; 9.8)$, accordingly.

Conclusion. The clinical investigations results in patients after the coronary shunting doing have shown, that while performance of artificial blood circulation the BIS indices on the level of $40-55$ are corresponding to optimal depth of anesthesia, what guarantees the lowering of the POCD occurrence rate in early postoperative period and in 3 mo postoperatively. The BIS indices values lesser than 40 constitute a risk factor for the POCD occurrence during the coronary arteries shunting procedure in conditions of artificial blood circulation. Keywords: depth of anesthesia; artificial blood circulation; cognitive dysfunction; aorto-coronary shunting. 
Післяопераційна когнітивна дисфункція (ПОКд) є частим ускладненням хірургічних втручань [1]. Щорічно у світі виконують понад 100 млн оперативних втручань у різних галузях хірургії та з використанням різних методів знеболювання [2]. Згідно з даними світової літератури після загальнохірургічних втручань частота виникнення ПОКД сягає 17\% у ранньому періоді, після кардіохірургічних - 43\% у ранньому періоді та 16\% через 3 міс [3].

Когнітивні функції головного мозку пов'язані з процесом раціонального пізнання світу. До них відносять пам'ять, гнозис, праксис, мову, увагу та інтелект [4]. Порушення цих функцій позначають відповідно термінами амнезія, агнозія, апраксія, афазія, неуважність та олігофренія. Когнітивні порушення класифікують також як легкі, помірні та тяжкі.

Щорічно в Україні близько 10000 пацієнтів виконують кардіохірургічні втручання різного типу. Саме кардіохірургія найчастіше супроводжується різного роду неврологічними наслідками, які так само найчастіше спричиняють післяопераційну захворюваність та смертність [5].

Згідно з рекомендаціями Американської асоціації кардіологів та кардіохірургів їх класифікують на два типи [6]: до 1-го відносять неврологічні ураження, що призвели до смерті мозку, нефатального інсульту та вперше виявленої транзиторної ішемічної атаки, до 2-го - делірій та ПОКД. Найбільш значущими клінічними неврологічними наслідками кардіохірургічних операцій $є$ інсульт та ПОКД, які діагностують у 1,6\% пацієнтів [7] після ізольованого аорто-коронарного шунтування (АКШ), проте підхід до визначення частоти та причин виникнення ПОКд, ї діагностики та лікування має бути більш комплексним.

Terri G. Monka та Catherine C. Priceb спостерігали безумовний вплив анестезії та анестетиків на виникнення когнітивних розладів у післяопераційному періоді [8]. У той же час питання впливу глибини анестезії на виникнення когнітивних розладів у кардіохірургічних хворих $є$ багатофакторним та потребує подальшого дослідження. Експериментальні дані дуже різноманітні, а дослідження з цього приводу перебувають на початковому етапі [9].

Мета дослідження: проаналізувати залежність виникнення ПОКД від глибини анестезії у хворих після оперативного втручання з приводу IXC - коронарного шунтування в умовах штучного кровообігу.

\section{Матеріали і методи дослідження}

У ретроспективному обсерваційному одноцентровому дослідженні взяли участь 79 пацієнтів з IXC, яким у період з 2013 по 2017 р. було виконано шунтування коронарних судин в Інституті серця МОЗ України. Попередньо в дослідження було включено 112 пацієнтів, проте 33 пацієнти 3 нього вибули: 1 - у зв'язку з тривалою штучною вентиляцією легенів (ШВЛ), 1 - у зв'язку із реторакотомією з хірургічних причин, у 10 пацієнтів були артефакти на моніторі BIS, 21 пацієнт не з'явився на повторне тестування через 3 міс після шунтування. Вибірка була сформована за заздалегідь визначеними критеріями щодо пацієнтів, яким після проведення коронаровентрикулографії (КВГ) було рекомендовано виконання оперативного втручання - коронарного шунтування в умовах штучного кровообігу.
Серед обстежених пацієнтів було 65 (82,3\%) чоловіків та $14(17,7 \%)$ жінок віком $(59,5 \pm 7,9)$ року (середнє значення \pm стандартне відхилення). Хворих з цукровим діабетом (ЦД) 2-го типу було 12 (15,2\%), з виразковою хворобою шлунка та дванадцятипалої кишки - 9 (11,4\%), 3 хронічними обструктивними захворюваннями легенів 4 (5,1\%), 4 (5,1\%) хворих мали подагру в анамнезі.

У 7 (8,9\%) пацієнтів була стенокардія напруги II функціонального класу (ФК), у 60 (75,9\%) - ІІІ ФК, у 12 (15,2\%) - прогресуюча стенокардія. Інфаркт в анамнезі мали 26 (32,9\%) пацієнтів, причому 2 (7,7\%) з них попередньо було виконано стентування коронарних артерій. За даними ехокардіологічного дослідження 73 (92,4\%) пацієнти мали збережену фракцію викиду лівого шлуночка. Ознаки хронічної серцевої недостатності спостерігали у всіх пацієнтів: у 6 (7,6\%) - І стадії та 73 (92,4\%) - ІІ стадії за класифікацією М. Д. Стражеска - В. Х. Василенка. Всі пацієнти мали гіпертонічну хворобу: 26 (32,9\%) - II стадії, 53 (67,1\%) - III стадії.

Тривалість операції в середньому становила $(184,2 \pm$ $28,1)$ хв, ШВЛ - $(8,7 \pm 4,0)$ год, штучного кровообігу - $(79,8$ $\pm 15,3)$ хв, рівень інтраопераційної крововтрати - $(285,6$ $\pm 40,5)$ мл, післяопераційної - $(485,3 \pm 199,2)$ мл, тривалість перебування у відділенні інтенсивної терапії (BIT) $(45,3 \pm 7,5)$ год, у клініці - $(11,9 \pm 3,9)$ дня.

АКШ виконали 57 (80,3\%) пацієнтам, АКШ у поєднанні 3 накладанням мамарокоронарного анастомоза (МКШ) - 12 (15,2\%), середня кількість накладених анастомозів становила 2,9 $\pm 0,5$.

Критерії, які були підставою невключення пацієнтів до дослідження: вік до 18 років; наявні в анамнезі відкриті кардіохірургічні або нейрохірургічні втручання у будьякі строки; будь-яке використання наркозу протягом останніх 12 міс під час будь-якого оперативного втручання; наявність гемодинамічно значущого (понад 50\%) стенозу каротидних артерій; виражений дефіцит зору або слуху; алкогольна або наркотична залежність, деменція; перебування на стаціонарному лікуванні більше 4 тиж. У дослідження не включали також пацієнтів, які потребували комбінованих втручань з приводу клапанної дисфункції тощо, що передбачали відкриття порожнин серця у ході хірургічного втручання, та пацієнтів, у яких неможливою була реєстрація електроенцефалограми.

Всім пацієнтам проводили транстемпоральне вимірювання швидкості кровотоку по середній мозковій артерії. Неможливість його реєстрації або інтраопераційне зниження зазначеного показника більше ніж на 10\% від вихідного значення були підставами для виключення пацієнтів 3 дослідження.

У передопераційному періоді всім хворим проводили стандартний комплекс обстежень, необхідних для відбору та підготовки до виконання коронарного шунтування в умовах штучного кровообігу: опитування, антропометричні вимірювання, об'єктивний огляд, параклінічні лабораторні дослідження, електрокардіографія, ехокардіографія, ультразвукове дослідження внутрішніх органів, щитоподібної залози, магістральних артерій та вен, дуплексне сканування судин шиї та голови, езофагогастродуоденофіброскопія, КВГ. 
Усіх пацієнтів, включених у дослідження, до операції обстежував невролог з метою виключення неврологічних відхилень. Обстеження включало оцінку психічного та когнітивного статусу, діяльності рефлекторно-рухової сфери (тонусу та сили основних м'язових груп, наявності та вираженості основних шкірних та сухожильних рефлексів, наявності патологічних рефлексів Бабінського, Жуковського, Шеффера тощо), функціонування чутливої сфери (тестування больової та пропріоцептивної чутливості) з оцінкою двомірно-просторового орієнтування (стереогноз), координаторної сфери (пальце-носова та колінно-п'яткова проби, проби на адіадохокінез, складна та проста проба Ромберга), стану вегетативної сфери (визначення дермографізму, пітливості) та функції тазових органів.

Для анестезіологічного забезпечення операцій у обстежуваних пацієнтів використовували комбіновану схему анестезії, затверджену в Інституті серця МОЗ України: індукція - севофлуран 4 об\% з пропофолом 1,5 - 2,5 мг/кг та фентанілом 1 мкг /кг; підтримка анестезії - севофлуран 1,2 - 2,5 мінімальної альвеолярної концентрації (МАК); міорелаксація - аркурон 0,07 - 0,08 мг/кг; аналгезія - загальна доза фентанілу 12,5 - 25 мкг/кг.

Штучний кровообіг, який забезпечували відповідно до «Протоколу перфузії у хворих на ішемічну хворобу серця», затвердженого в Інституті серця МОЗ України, передбачав використання мембранних оксигенаторів з наборами кровопровідних магістралей з артеріальним фільтром, підтримку помірної гіпотермії $\left(32-34{ }^{\circ} \mathrm{C}\right)$, пульсуючого кровотоку та застосування електроплегії (штучної фібриляціi).

Нейрокогнітивні тести застосовували за 3 дні до оперативного втручання, на 7-й день після оперативного втручання та на 3-й міс після виписки зі стаціонару. Нейропсихологічне тестування проводили після отримання від пацієнтів інформованої згоди. Використовували такі тести: шкалу оцінки психічного статусу (Mini Mental state examination - MMSE) [10], тест за методикою Grooved pegboard і тест за методикою Trial Making Test Part A [11].

Усіх включених у дослідження пацієнтів розподілили на дві групи за єдиним критерієм - в залежності від глибини анестезії, яку підтримували під час перфузіі. До 1-ї групи увійшли 40 пацієнтів, у яких під час анестезії показник BIS підтримували на рівні менше 40. До 2-ї групи увійшли 39 пацієнтів, у яких зазначений показник підтримували на рівні $40-55$.

Отримані результати опрацьовували статистично за допомогою програмного пакета IBN SPSS Statistics v. 23.0. Розподіл кількісних даних перевіряли за критерієм Колмогорова-Смирнова. Центральну тенденцію та варіацію кількісних показників, розподілених ненормально, позначали як медіана (міжквартильний інтервал), за нормального розподілу - як середнє значення та стандартне відхилення.

Кількісні показники порівнювали за допомогою t-критерію Вілкоксона або t-критерію Ст'юдента. Для порівняння абсолютної і відносної (\%) частоти якісних показників використано таблиці спряженості з оцінюванням за критерієм $\chi^{2}$ Пірсона. Рівнем статистичної значущості вважали $\mathrm{p}<0,05$ (з урахуванням поправки Бонферроні).

\section{Результати}

Порівнювані групи пацієнтів суттєво не відрізнялися за віком, гендерною структурою та антропометричними даними. Групи були репрезентативними та не мали значущих відмінностей за супутньою патологією, стадіями гіпертонічної хвороби, серцевої недостатності, ФК стенокардії та фракцією викиду лівого шлуночка. Не було відмінностей за кількістю виявлених інфарктів в анамнезі та попередньо виконаних стентувань коронарних судин, тривалістю перебування у ВІТ та клініці.

Тривалість операції у пацієнтів $1-\ddot{і}$ групи становила $(183,3 \pm 27,3)$ хв, 2-ї групи - $(185,5 \pm 30,1)$ хв (p=0,364); штучного кровообігу у пацієнтів $1-\ddot{1}$ групи - $(81,2 \pm 16,1)$ хв, 2-ї групи - $(75,7 \pm 15,1)$ хв (p=0,210). Паціенти 1-ї групи перебували на ШВЛ протягом $(9 \pm 4,1)$ год, $2-і ̈$ групи - $(8,6 \pm 4,3)$ год ( $=0,415)$. Об'єм інтраопераційної крововтрати у $1-и ̆$ групі становив $(291,3 \pm 68,8)$ мл, у $2-и ̆-$ $(278,2 \pm 37,7)$ мл $(\mathrm{p}=0,108)$; післяопераційної - $(525,8 \pm$ $211,3)$ та $(477,9 \pm 190,4)$ мл $(\mathrm{p}=0,116)$ відповідно.

Застосування тесту MMSE продемонструвало, що пацієнти 1-ї групи на 7-й день після операції набирали на $7,8 \%(14,2 ; 5,6)$, а через 3 міс - на 3,8\% $(7,3 ; 3,4)$ менше балів у порівнянні з показниками до операції. Пацієнти 2-ї групи на 7-й день після операції набирали на 4,3\% (8,3; 4,3) менше балів ( кість балів, яку вони набирали через 3 міс після операціі, не відрізнялась від доопераційної (5,3; 0).

Результати тесту візуальної уваги (Trial Making Test Part А) були такими. Пацієнти 1-ї групи на 7-й день після операції витрачали на виконання тестованих завдань на 13,8\% $(11 ; 16,5)$, а через 3 міс - на 3,3\% (0; 5,7) більше часу у порівнянні з доопераційним показником. У 2-й групі пацієнти на 7-й день після операції витрачали на виконання тесту на 3\% $(-2,4 ; 5,7)$ більше часу $(\mathrm{p}=0,005)$, а через 3 міс - на 2,6\% (-3,7; 2,9) менше часу, ніж до операції $(\mathrm{p}=0,001)$.

Тестування за методикою Grooved pegboard продемонструвало, що пацієнти 1-ї групи на 7-й день після операції витрачали на виконання тесту на $8 \%(5,5 ; 10,9)$, а через 3 міс - на 4,8\% $(2,5 ; 9,4)$ більше часу, ніж до оперативного втручання. Для пацієнтів 2-ї групи ці показники склали 7,1\% (5,2; 12,3) (p=0,002) та 3,6\% $(2,4 ; 9,8)(\mathrm{p}=0,003)$ відповідно.

\section{Обговорення}

Періопераційні когнітивні порушення, включаючи післяопераційний делірій та ПОКд, призводять до збільшення смертності хворих після оперативних втручань [12]. Серед численних факторів, що впливають на ризик виникнення ПОКД, особливе місце займає анестезія. Різні рівні глибини анестезії по-різному впливають на пацієнта: більш глибока анестезія не сприяє швидкому відновленню у післяопераційному періоді, тоді як менш глибока може призвести до психологічної травми через можливість інтраопераційного усвідомлення та пробудження пацієнта [13]. Дискусії з приводу впливу глибини анестезії на когнітивні порушення тривають, консенсусного рішення немає, проте фахівці сходяться на думці, що це питання як дуже перспективне варто більш детально дослідити [14, 15]. 


\section{Висновки}

1. Результати клінічних досліджень у хворих, яким було виконано коронарне шунтування, показали, що під час штучного кровообігу показники BIS на рівні 40 - 55 відповідають оптимальній глибині анестезії, що є запорукою зменшення частоти виникнення ПОКД у ранньому періоді та через 3 міс після оперативного втручання.

2. Фактором ризику виникнення ПОКД під час шунтування коронарних артерій в умовах штучного кровообігу є показники BIS менші 40.

\section{References}

1. Ghoneim MM, Block RI. Clinical, methodological and theoretical issues in the assessment of cognition after anaesthesia and surgery: a review. Eur J Anaesthesiol. 2012;29:409-22. doi: 10.1097/EJA.0b013e328356bd6e.

2. Bianchi SL, Tran T, Liu C, Lin S, Li Y, Keller JM, Eckenhoff RG, Eckenhoff MF. Brain and behavior changes in 12-month-old Tg2576 and nontransgenic mice exposed to anesthetics. Neurobiol Aging. 2007;29:100210. doi:10.1016/j.neurobiolaging.2007.02.009.

3. Evered L, Scott DA, Silbert B, Maruff P. Postoperative cognitive dysfunction is independent of type of surgery and anesthetic. Anesth Analg. 2011 May;112(5):1179-85. doi: 10.1097/01.SA.0000410262.98051.76.

4. Usenko LV, Rizk SE, Krishtafor AA. Prevention and correction of postoperative cognitive dysfunction in eldery patients (methodological reccomendations). International neurological journal. 2008;3(19):99-110. [In Russian]

5. McKhann GM, Goldsborough MA, Borowicz LM Jr. Cognitive outcome after coronary artery bypass: a one-year prospective study. Ann Thorac Surg 1997;63:510-5. doi: 10.1016/s0003-4975(96)01057-0.

6. Hillis LD, Smith PK, Anderson JL, Bittl JA, Bridges CR, Byrne JG, et al. 2011 ACCF/AHA Guideline for Coronary Artery Bypass Graft Sur- gery: executive summary: a report of the American College of Cardiology Foundation/American Heart Association Task Force on Practice Guidelines; Anesth Analg. 2012 Jan; 114(1):11-45. doi: 10.1213/ANE. $0 \mathrm{~b} 013 \mathrm{e} 3182407 \mathrm{c} 25$.

7. Selnes O, Gottesman R, Grega M. Cognitive and neurologic outcomes after coronary-artery bypass surgery. N Engl J Med 2012;366: 250-7. doi: 10.1056/nejmra1100109.

8. Terri G. Monka, Catherine C. Priceb. Postoperative cognitive disorders. Curr Opin Crit Care. 2011 Aug; 17(4): 10. p.1097. doi:10.1097/ mcc.0b013e328348bece.

9. Luk TTH, Jia B, Pang YET, Lau VNM, Lam CKM, Chu MHM. Depth of Anesthesia and Postoperative Delirium. Curr Anesthesiol Rep. 2015;5(1):1-9. doi: 10.1007/s40140-014-0088-z.

10. Hawkins MA, Gathright EC, Gunstad J. The MoCA and MMSE as screeners for cognitive impairment in a heart failure population: a study with comprehensive neuropsychological testing. Heart Lung. 2014 SepOct;43(5):462-8. doi: 10.1016/j.hrtlng.2014.05.011.

11. Murkin J, Newman S, Stump D, Blumenthal J. Statement of consensus on assessment of neurobehavioral outcomes after cardiac surgery. Ann Thorac Surg 1995;59:1289-95. PMID: 7733754.

12. Whitlock EL, Vannucci A, Avidan MS. Postoperative delirium. Minerva Anestesiol 2011;10:448-56. PMID: 21483389.

13. Sury MRJ, Smith JH. Deep sedation and minimal anesthesia. Paediatr Anaesth 2008;18:18-24. doi: 10.1111/j.1460-9592.2007.02379.x.

14. Jildenstål PK, Rawal N, Hallén JL, Berggren L, Jakobsson JG. Perioperative management in order to minimise postoperative delirium and postoperative cognitive dysfunction: Results from a Swedish web-based survey Ann Med Surg (Lond). 2014 Aug 12;3(3):100-7. doi: 10.1016/j. amsu.2014.07.001.

15. Shu AH, Wang Q, Chen XB. Effect of different depths of anesthesia on postoperative cognitive function in laparoscopic patients: a randomized clinical trial. Curr Med Res Opin. 2015;31(10):1883-7. doi: 10.1185/03007995.2015.1075968. 